Marc Bühlmann*, Adrian Vatter, Oliver Dlabac and Hans-Peter Schaub

\title{
Liberal and Radical Democracies: The Swiss Cantons Compared
}

\begin{abstract}
This article examines the widespread hypothesis that German-speaking Swiss cantons exhibit radical-democratic characteristics, while the Latin cantons possess stronger liberal-representative democratic profiles. Empirical and multi-dimensional measuring of the quality of democracy in the cantons shows that this hypothesis does not do the complexity of cantonal democracy justice. Today's position of the cantons along the axes of liberal and radical democracy is best explained with reference to the strong liberal and democratic constitutional movements within the cantons during the middle of the $19^{\text {th }}$ century.
\end{abstract}

Keywords: measuring the quality of democracy; liberal democracy; radical democracy; Switzerland; path dependence (Erblast hypothesis).

DOI 10.1515/wpsr-2014-0017

\section{Introduction}

A key concern of empirical research on democracy is to assess and compare different types of political regimes. Measuring democracy plays a prominent role. Its origins lie in the works of Lipset (1959) and Dahl (1956) and have been continued and developed in numerous other studies (for a summary see: Lauth 2004; Pickel and Pickel 2006). The existing empirical works distinguish themselves noticeably in that they focus almost exclusively on the national level while the subnational level is practically ignored. This gap in the research

*Corresponding author: Marc Bühlmann, Institute of Political Science, University of Bern, Switzerland, e-mail: marc.buehlmann@ipw.unibe.ch

Adrian Vatter and Hans-Peter Schaub: Institute of Political Science, University of Bern, Switzerland

Oliver Dlabac: Department of Political Science, University of Zurich, Switzerland 
cannot be filled by simply transferring national democracy measurements onto subnational entities for at least two reasons. Firstly, the existing measurements cannot explain the variation in the quality of democracy across subnational entities, particularly in federal systems (Kropp et al. 2008). Secondly, existing measurements almost entirely disregard direct-democratic settings which are more widely used at the subnational than the national level. In order to understand the Swiss political system, which will be more closely analysed below, an analysis of the cantons is important given that this was where modern Swiss democracy developed (Kölz 2004: p. 41). We argue that an examination of the varying quality of complex democratic decision-making structures in Switzerland is only possible through comparatively applied analyses of cantonal systems. These, in turn, have to be based on suitable and newly developed measurements of democracy.

The Swiss cantons like to be considered ideal "research laboratories" (Vatter 2002, 2006; Freitag 2005; Selb 2006; Bühlmann et al. 2009a) where different political institutions, with varying impacts on political conduct and public policy, can be reviewed. There are a number of projects concentrating on cantonal patterns of democracy as defined by Lijphart's dimensions of power sharing and their effects (Vatter 2002, 2007; Vatter and Freitag 2006, 2007). However, there is no literature that deals with the many facets of the quality of Swiss cantonal democracy, as is generally the case in international comparative research. Furthermore, there is currently no comparative longitudinal analysis of cantonal democratic systems that covers a greater period. Existing studies on patterns of cantonal democracy have, as a rule, not considered all 26 cantons, often excluding the smaller and/or Landsgemeinde cantons on the basis of their special characteristics. The goal of this article is to fill these gaps and present a theoretical and empirically-founded analysis of the democratic patterns and dimensions in all Swiss cantons. The multi-dimensional qualities of democracy in the cantons will be measured and analysed through a newly developed measuring instrument using expansive data. Our dual instrument is based on a democracy concept that simultaneously arranges liberal-representative and radical-participatory models of democracy into ideal types. Whereas the radicalparticipatory type comprises well-developed participatory options including radical participation, public accountability and the widest possible inclusion, the liberal type distinguishes itself through the emphasis on constitutional-legal guarantees and strong horizontal-institutional as well as predominantly vertical-electoral controls. Both ideal types are distinguished by several dimensions, the characteristics of which were measured in the cantons at different points in time. 
Building on this new measuring instrument, the focus of this article is the empirical examination of the widespread language-cultural hypothesis of democracy-typical differences between the Latin and German-speaking cantons (Kriesi and Wisler 1996; Vatter 2002; Linder 2005, 2010; Freitag 2006; Ladner and Bühlmann 2007; Stadelmann-Steffen and Freitag 2011). Existing research assumes that the German-speaking cantons are characterized primarily by directdemocratic and participatory elements, while the Latin cantons are more liberalrepresentative oriented. In our article we present an alternative explanation for this hypothesis and test - based on the political Erblast hypothesis (Rose and Davies 1994) - whether the particular constitutional movements during the emergence of cantonal democratic regimes in the mid-19 ${ }^{\text {th }}$ century have left traces in the cantons today and whether they are the cause for the different cantonal patterns of democracy.

In the next section, we explain the measuring concept used to test the two concurrent hypotheses. The theoretical derivation and empirical examination of the two alternative explanations for the different implementations of democracy will be dealt with in Sections 3 and 4, with conclusions presented in Section 5.

\section{Liberal and Radical Democracies - A Dual Concept of Measurement}

Research in the field of the empirical investigation of democracy has recently expanded: measuring democracy no longer focuses solely on measuring the differences between democracies and autocracies, but increasingly also on the evaluation of the quality of established democratic systems (Bühlmann et al. $2012 a, b)$. To this end one of the central requirements is the provision of a coherent concept of democracy as a basis for measuring democracy. There are already several proposals for the measurement of the quality of democracy (Bühlmann et al. 2009b); however these lack the inclusion of instruments of direct democracy (Altman 2013), and also fail to analyse subnational entities.

Swiss cantons are distinguished in international comparison in that they provide citizens with highly developed means for direct participation (Vatter 2002, 2006). An instrument that is able to adequately measure the subnational quality of democracy in the cantons must incorporate this participatory element and be based on a sufficiently broad concept of democracy (Bühlmann et al. 2009b). Such a concept is developed through two basic channels of democratic thought which have particularly shaped the Swiss cantons: the liberal and the 
radical models of democracy. ${ }^{1}$ While the liberal model is based on constitutionally guaranteed freedom rights, separation of powers and representation, the radical model of democracy strives for the maximum direct participation of all citizens in public consensus-building proceedings and direct-democratic decision-making (Held 2006). The dual measuring instrument presented in this article combines the central aspects of both democratic models, important both in theory and in the Swiss environment, and thereby allows their simultaneous measurement. The relevant criteria for measuring the quality of democracy are determined by the requirements of particular democratic concepts. Three central dimensions of democratic quality each derive from the liberal and radical theoretical traditions. This deduction represents the first step in conceptualising the measuring instrument. The six dimensions are more precisely defined by various components in further deductive steps, and these components are then measured using subcomponents and indicators. We next examine the theoretical foundation of the six dimensions and their components (cf. also Table 1).

\subsection{Liberal Dimensions of Democracy}

The underlying liberal-democratic model is based on Locke's liberal constitutionalism, Montesquieu's separation of powers, and the idea of direct government responsibility vis-à-vis the electorate pursuant to Bentham, James Mill, and John Stuart Mill. Variations of these three dimensions run throughout liberal-democratic theory and have become key factors in theoretical and empirical research on democracy. In connection with liberal constitutionalism, freedom rights as well as aspects of the rule of law are discussed and measured. With regard to the separation of powers, the focus is on the concept of horizontal accountability, while governmental responsibility vis-à-vis the electorate is discussed in terms of electoral accountability. An explanation of these three dimensions follows.

\footnotetext{
1 The terms "radical" and "liberal" simultaneously refer to debates on the development of federal and cantonal citizens' rights which, in $19^{\text {th }}$ century Switzerland, were predominantly under the control of the liberal and radical (and later on the democrat) wings of the liberal party (cf. Kölz 1992; Vatter 2002). Gruner (1977: 75f) positions the liberal wing's ideological roots alongside the ideas of Benjamin Constant in that what is required is a strong representative democracy and heavy restrictions on the state in favour of the, above all, economically independent individual. By contrast, radicalism, heavily influenced by Ignaz Paul Troxler, holds citizens above every constitutional legislative authority. Radicals called for universal suffrage and the citizens' right to demand a review of the constitution at an early stage.
} 


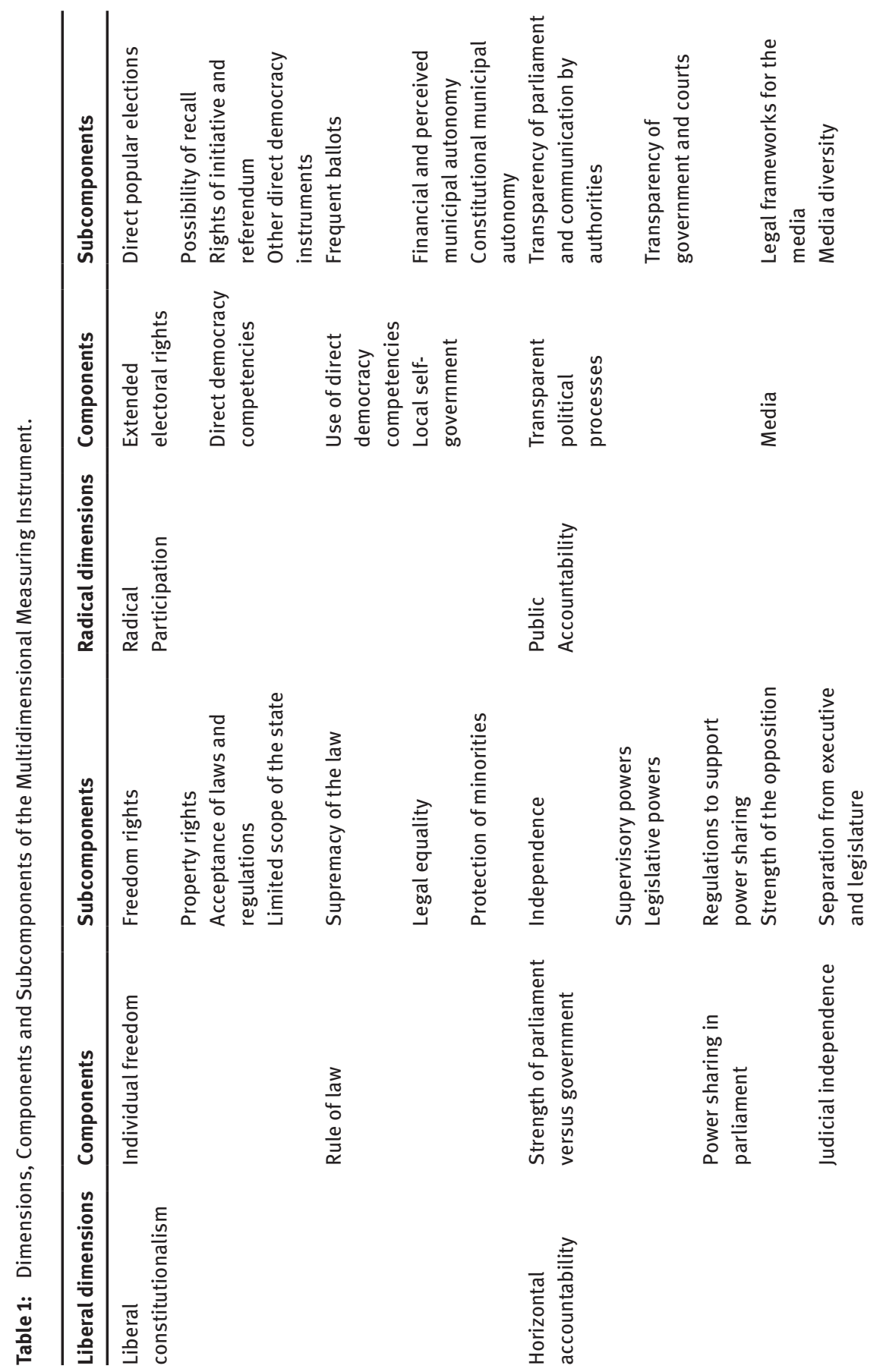




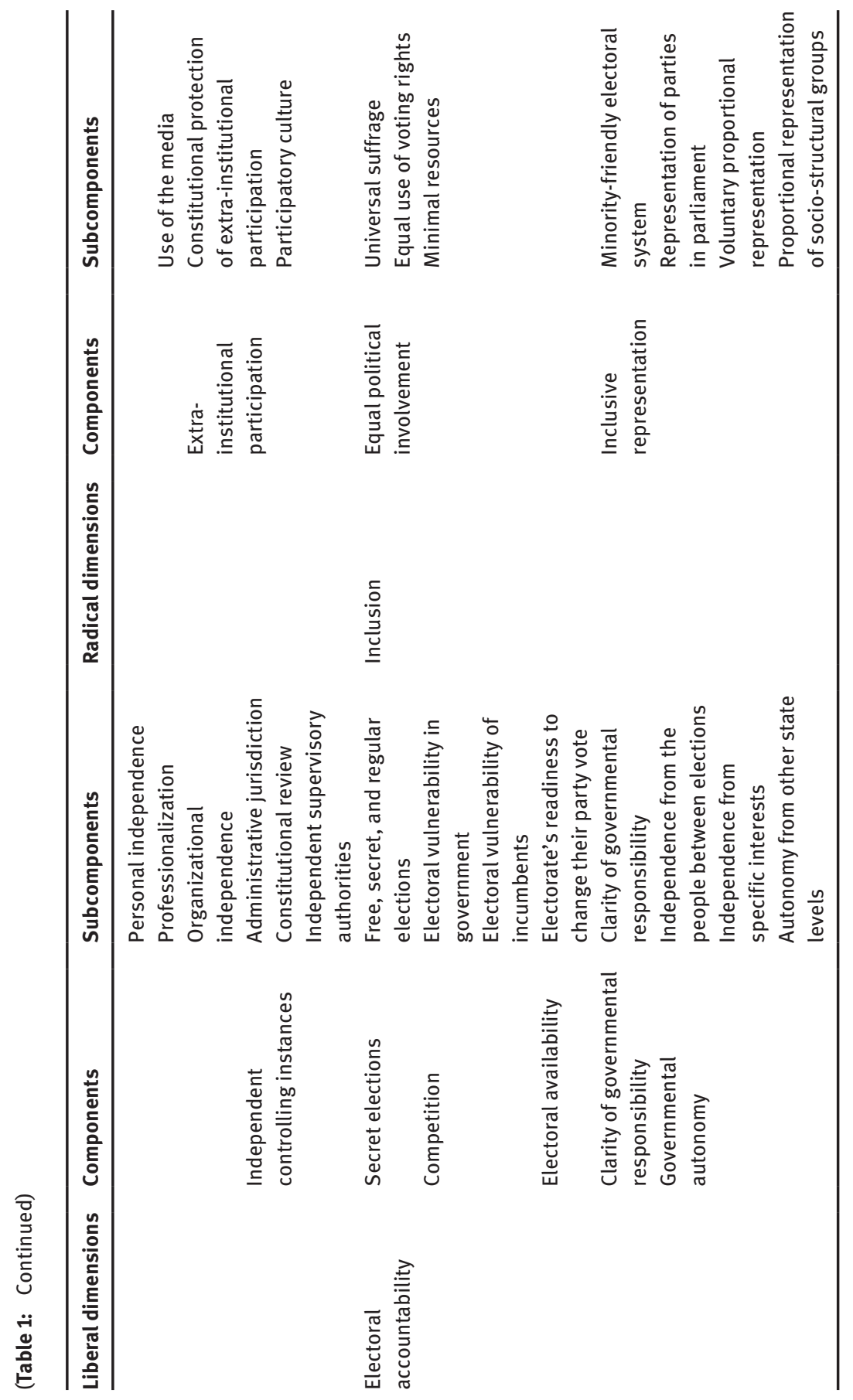




\subsubsection{Liberal Constitutionalism}

As the first dimension of the liberal-democratic model, liberal constitutionalism consists of two components. These were cemented in Locke's (1963 [1689]) concept of constitutionalism whereby government authorities must be impersonal and constitutionally restricted to protect individual freedom:

1. Individual freedom. Over time, liberal traditional thought has extended the catalogue of demands for individual freedom rights. While Locke (1963 [1689]), in his theory of a social contract, acts on the assumption of a prestate right to life, freedom, and property, Bentham (1960 [1776], 1843 [1831]) and James Mill (1937 [1820]) maintain that the freedoms of press, speech and association are instruments against corruption. Finally, John Stuart Mill (1859) highlights the right to one's own personal life. These freedoms presuppose, from a liberal perspective, a limit to the influence of the state. It is this limitation that ensures the utilitarian idea of free transactions between individuals (Mill 1937 [1820]; Bentham 1960 [1776]). The effective protection of these freedoms depends on the extent to which democratically applied laws and regulations are accepted and complied with by individual citizens (Beetham 2004).

2. Rule of law. Locke insists that without restrictions on authority, tyranny will ensue (1963 [1689], ch. 18). Montesquieu (1994 [1748]) supports a system of positive legislation that sets inviolable boundaries for actions of the state to limit despotism and corruption. So that democracy does not revert to the "tyranny of the majority" (Tocqueville 2006 [1835]), basic human and minority rights must be placed out of reach of majority decision-making (Diamond and Morlino 2004; O'Donnell 2004). The basis of inviolable national justice implies formal as well as material legal obligations of the state. With the principle of legal equality (Montesquieu 1994 [1748]), equal access to the courts and equal treatment in the eyes of the law is required (Beetham 2004).

\subsubsection{Horizontal Accountability}

The idea of the separation of powers is an early and fundamental component of liberal-democratic theory. The control of government and adherence to constitutional principles must be secured through a mutual balance of power. In modern research on democracy, separation of powers is studied through the concept of horizontal accountability - the second dimension of the liberal-democratic type used here. Through a network of relatively autonomous institutions, authorities 
mutually control each other and make a commitment to act both lawfully and constitutionally (O’Donnell 1994: p. 61; Schedler 1999: pp. 14-18). Horizontal accountability is measured using the following four components:

1. Strength of parliament versus government. Locke (1963) [1689]) emphasizes that only the separation of power between the executive and the legislative branches guarantees that both are subordinate to the law, rather than being allowed to pursue private interests. The idea of checks and balances later became the core of the Federalist Papers (Hamilton et al. 1788: Art 47-51). Current research on democracy also emphasizes the need for a strong parliament capable of keeping the reins on government (Beetham and Boyle 1995: pp. 66-74).

2. Power-sharing within parliament. In modern representative democracies, the relationship between the executive and the legislative is co-determined in a decisive way by power-sharing arrangements within parliament and the strength of the opposition (Altman and Pérez-Liñan 2002).

3. Judicial independence. An independent judiciary is essential for the security of individual rights and prevention against oppression (Montesquieu 1994 [1748]: Book XI, Ch. 6). Madison (Hamilton et al. 1788: Art 51) also demands professional, politically independent courts; a concept incompatible with the election of judges and term-of-office restrictions.

4. Independent controlling instances. Abuse of government power is ultimately restricted in that political decisions are subject to judicial and constitutional review (Hayek 1960). To prevent corruption and despotism, it is further necessary that the state apparatus is controlled by an independent administrative court. Additional "agencies of protection" like auditing commissions, anti-corruption authorities or Ombudsmen can further protect the rights of citizens against abuses of power (Beetham 2004: pp. 68, 71; Diamond and Morlino 2005: p. xxi).

\subsubsection{Electoral Accountability}

In the liberal tradition of political thought, the state is the creator of laws for individuals who entrust themselves to the power of government in order to implement citizens' objectives (Locke 1963 [1689]: pp. 308, 395). At the same time, a liberal-democratic model relies on the delegation of power to representatives as a proven tool against the danger of a tyranny of the majority (Hamilton et al. 1788: Art. 10): whereas citizens allow themselves to be guided by their own interests, representative institutions offer a place for professional deliberation. In this way, democracies confront the question of how 
citizens' representatives can be held accountable. The solution is provided by secret and competitive elections that guarantee a responsive legislature (Bentham 1843 [1831]: p. 47). Contemporary research on democracy examines this problem under the heading of "electoral accountability," understood as the relationship of accountability between rulers and voters (O’Donnell 2004). This third dimension of liberal democracy is conceptualized by five different components:

1. Free, secret and regular elections. Regularly held elections are equal to a sanctioning mechanism, forcing representatives to consider the will of voters in order to be re-elected. In this way, ballot secrecy should guarantee that citizens can express their preferences free from undue influence.

2. Competition. Supported by Bartolini (1999, 2000), different facets of electoral competitions can be differentiated from one another. The electoral race in democratic elections requires a system as open as possible to new competitors ("contestability"), while the elections themselves should be as competitive as possible ("electoral vulnerability").

3. Electoral availability. Bartolini $(1999,2000)$ further suggests that an important factor of competition, and a condition for electoral accountability, is "electoral availability," meaning the fundamental willingness of voters to change their party preference.

4. Clarity of responsibility. So that the electorate can consider sanctioning current public officials, a clear assignment of responsibilities is needed. However, where there is a large number of coalition partners, that is no longer the case (Powell and Whitten 1993: pp. 399-400).

5. Governmental autonomy. A functioning relationship of accountability between government and voters assumes not only that regular elections act as (potential) sanctions, but also that governments possess a certain action autonomy. So that the chain of responsibility comes full circle, governments must be able to implement democratically made decisions. To do this, governments require not only protection against attempts by illegitimate interests to exert influence (cf. Merkel 2004), but also a certain degree of sovereignty over other levels of the state as well as over protests and blocking attempts by citizens themselves (Pitkin 1967).

\subsection{Radical Dimensions of Democracy}

The radical-democratic model, the second pillar of our dual measuring strategy, is based on participatory and at times deliberative theories of democracy as summarized by Cohen and Fung (2004) under the heading of "radical 
democracy."2 The origins of radical theories of democracy stem from ancient Athenian's public voting by show of hands, Rousseau's republicanism, and Marxist democratic theory (cf. Held 2006: pp. 5, 187). Like the liberal tradition above, the radical tradition of thought can equally be understood as having three key dimensions: radical participation, public accountability, and inclusion.

\subsubsection{Radical Participation}

According to radical-democratic theory, active participation in public life promotes self-fulfilment and the development of civic virtues. Significant value is placed on the political participation of individuals (Pateman 1970: pp. 25, 43; Macpherson 1977: pp. 114-115; Barber 1984: pp. 117-162, 232). Diverse and comprehensive participatory mechanisms are therefore required (Pateman 1970; Barber 1984: p. 272), described in turn by the following four components:

1. Extended electoral rights. Although radical democrats are sceptical of the delegation of competencies from citizens to representative organs (Rousseau 1762: pp. 235-239; Barber 1984: pp. 145-147), they generally accept that a pure system of direct-democratic self-government would exceed citizens' resources (e.g. Barber 1984: p. 267). Insofar as delegation is inevitable, citizens must entrust powers of control and, if need be, of sanction to their representatives. Not only members of the legislative but also those of the executive and judicative should be chosen through direct popular vote. Moreover, a recall of representatives should also be possible.

2. Direct democracy. The enabling of more refined forms of direct-democratic participation and the power of citizens even in-between elections is regarded as very important in the radical model. Citizens must have the power to both correct the decisions of their representatives and place new concerns onto the agenda (Macpherson 1983: p. 132; Barber 1984: pp. 281-289; cf. also Rousseau 1762).

3. Use of direct democracy. The effective and regular use of formal participatory rights is necessary to achieve the goals of individual self-realization and collective self-government.

4. Local self-government. According to radical thought, self-government is best achieved where citizens are most directly affected and where they can have

2 Participatory and deliberative theories of democracy are also presented by Schmidt (2010: pp. 236-253), for example, as characteristics of a collective stream (cf. also Saward 2001 and Fung 2006). 
the most direct influence. That is why strong local autonomy is a central requirement of participatory democratic theory (Macpherson 1977: p. 108; Barber 1984: pp. 267-273).

\subsubsection{Public Accountability}

From a radical-democractic perspective, elections and the separation of powers alone are not enough for citizens to effectively hold their representatives to account; additional mechanisms of public discourse as well as informal means of participation are required (Smulovitz and Peruzzotti 2000: pp. 149, 151; Young 2000: pp. 153, 173-177; Lauth 2004). Public accountability, the second dimension of radical democracy, is summarized by way of three components:

1. Transparency. Information about political processes is a central requirement for accountability. The easier it is to obtain such information, the more transparently the political process is implemented and presented and the more likely it is that the public can enter into a meaningful debate with the political elite and hold them to account (cf. Beetham 1994: p. 37; Diamond and Morlino 2004; Schmitter 2005).

2. Media. Public debate as a central component of functioning public accountability should not only be conducted between authorities and citizens but should also take place within an active public environment. Independent and varied media create a platform for different views so that no one is excluded (cf. Cohen 1989: pp. 22-23; Voltmer 2000). Furthermore, as "watchdogs" or a "fourth estate," the media can take on an autonomous control function (Peruzzotti and Smulovitz 2006). How much citizens benefit from varied and critical media ultimately depends on the extent to which they are actually utilized.

3. Extra-institutional participation. Even extra-institutional forms of participation can be channels for the registration of preferences and can put decision-makers who behave unresponsively under pressure (Smulovitz and Peruzzotti 2000: pp. 151-152; Young 2001). A broad and constitutionally secure participatory culture with politically active citizens and strong civil society organizations not only enriches public debate, but also allows for additional control over public officials (cf. Pateman 1970; Macpherson 1977: pp. 98-114; Barber 1984: pp. 264-266; Beetham 1994: pp. 29-30; Young 2000: p. 153; Merkel 2004: pp. 46-47; Peruzzotti and Smulovitz 2006: pp. 10-12). 


\subsubsection{Inclusion}

The third and final dimension of the radical model of democracy focusses on the equality of all individuals. All those affected by decisions are regarded as equally legitimated and able to take part in the decision-making process (cf. Rousseau 1762; Barber 1984: pp. 225-229; Dahl 1998: pp. 62-78; Schmidt 2010: pp. 236-241). Differences between individuals and social groups are expressly not seen as arguments against equal inclusion, but rather as enriching diversity to benefit rational decision-making (Dryzek 1990: pp. 41-42; Young 2000: pp. 81-120). Inclusion thus enhances both the quality as well as the legitimacy of political decisions. The concept of inclusion is based on two components:

1. Equal political involvement. Inclusion not only means the involvement of all affected citizens (cf. Goodin 2007), but more particularly equal involvement (cf. Cohen 1989: pp. 22-23; Young 2000: p. 11). In this regard, equal involvement anticipates the possession of political rights, especially in the form of universal voting rights (Paxton et al. 2003). In addition to formal equal rights, radical-democratic theory places value on an unbiased use of participatory rights independent of status or gender (cf. Smith 2009: pp. 20-22). Equal involvement is facilitated when the state provides minimal resources, allowing for the independent political activity of all individuals (Rousseau 1762: pp. 124-125; Pateman 1970: p. 22; cf. also Merkel 2004: pp. 44-45). This includes political education alongside material resources (Barber 1984; Dahl 1998: pp. 79-80).

2. Inclusive representation. As much as possible, the collective political and social diversity of society should be mirrored inside the representative organs. On the one hand, this means substantive representation, in other words adequate representation of the political views of citizens. On the other hand, what is required is also a descriptive representation of the socio-structural distribution inside these representative organs (Young 2000; Arato 2006). An institutional condition for inclusive representation is an electoral system that has the lowest possible electoral threshold (cf. Lijphart 2004; Arato 2006).

\subsection{The Multi-Dimensional Measuring Instrument}

The six democratic dimensions derived from both the liberal and the radical democracy models and their respective components and subcomponents (cf. Table 1) are the basis of the instrument that measures the quality of democracy. Following Munck and Verkuilen (2002), during the development of this instrument particular attention is paid to the three main challenges of operationali- 
zation: conceptualization, measurement, and aggregation (cf. Müller and Pickel 2007).

\subsubsection{Conceptualization}

The conceptualization of democratic quality proposed here is new in that it incorporates both established liberal-democratic as well as radical-democratic dimensions. The approach adopted allows for the qualities of distinctive liberal and radical democracies to be differentiated; the characteristics of the Swiss cantons can thus adequately be measured. The multi-dimensional conceptualization of the measuring instrument follows the methodological approach of Pickel and Pickel (2006): p. 269; cf. also Bühlmann et al. 2008, 2012a,b). The six dimensions examined are understood as abstract democratic functions. They can be realized with the help of the formal and informal institutional arrangements that appear at the component and subcomponent levels of the hierarchically-structured measuring instrument. ${ }^{3}$ This measuring concept also allows for a methodological critique of existing democracy measurement (Munck and Verkuilen 2002: pp. 12-14) in that the subordinate levels can be systematically and gradually derived from, and selectively defined by, the respective superior levels.

\subsubsection{Measurement}

Even though the subcomponents are more concrete than their dimensions (Table 1), they are still regarded as latent variables (cf. Bollen 1989: Ch. 6; Treier and Jackman 2008) which can only be measured in approximate terms, using a series of indicators. For the actual measurement, every subcomponent must therefore be operationalized using multiple quantifiable indicators. At the same time, our goal to reveal differences in quality between established and culturally similar subnational democracies requires a delicate and complex measuring instrument capable of capturing to which degree and in which way formal democratic institutions actually function in a given context (Bühlmann et al. 2008: p. 117; 2009: p. 459). That is why less formalized structural features ("rules in use") of cantonal democracy are factored in alongside formal institutions ("rules in form"). In other words, below the subcomponents are indicators obtained by

3 We have followed the functional research strategy as suggested by Lauth (2004) for the intercultural comparison of democracy: universal democratic functions can be realised using context-specific "functional equivalents." 
way of an analysis of legal texts (rules in form) as well as variables that measure the constitutional reality (rules in use) (e.g. survey data).

This approach can be illustrated using the operationalization of the "media" component in the context of the Swiss cantons. The contribution of the media to a high quality of public accountability is assessed, firstly, on the basis of statistics on the number and distribution of independent newspapers in a canton. Secondly, the degree of actual media use by citizens per canton is determined through survey data. Finally, on the basis of an analysis of legislative texts, the formal provisions for the promotion of information diversity and public access to the media are evaluated.

Through the application of such different data sources, the danger of systematic mistakes in measurement is reduced and the validity of our results thereby increased (Munck and Verkuilen 2002: pp. 15-16; Lauth 2004: pp. 306-307). The same also applies to the relatively high number of indicators: 371 indicators were originally allocated to the theoretically-derived subcomponents and tested accordingly by way of a factor analysis to detect their dimensionalities. As expected, not all indicators within the same subcomponents loaded onto the same factor. In such cases we also took into account qualitative considerations for the validity and reliability of the different indicators. This approach ultimately led to the operationalization of the 48 subcomponents by evaluating particular factors from the associated indicators (178 in total), whereby every subcomponent was determined on the basis of at least two indicators (for a list of all the indicators applied, see the Appendix).

During the collection of annual data for the 26 cantons from 1979 to 2009 we were able to rely on secondary sources to some extent, but primary data had to be collected for many indicators. However, it was impossible to find adequate data for all the years within the research period, so gaps were filled using constant time periods or through linear inter- or extrapolation. The method used for each indicator was carefully considered. ${ }^{4}$

\subsubsection{Aggregation}

The incremental aggregation from indicator- to dimension-level is based on the hierarchical, theoretical conceptualization of democracy's six dimensions. In the first step, and as already mentioned above, the selected theory-driven and empirically suitable indicators were condensed into 48 subcomponents through factor

4 Due to limited space, the exact coding details for each indicator cannot be shown here. The detailed codebook and raw data are available from the authors upon request. 
analyses. This factor-analytical approach to the determination of the subcomponents' values based on indicators reflects our understanding of the subcomponents as latent variables. In the first step of aggregation, none of the theoretical constructs were aggregated, although relatively meaningful theoretical conclusions would be available. ${ }^{5}$

In the second step, the factors of the subcomponents were standardized and condensed into the corresponding components. The averages of the standardized component values then ultimately represent the six dimensions. In this way, every element of the corresponding normative criteria matrix is incorporated with the same weight. ${ }^{6}$ The averaging explicitly derives from ancillary connections between the (sub)components, meaning that a low value in one (sub)component can be compensated by a higher value in another.

\section{Two Concurrent Hypotheses}

The new measuring instrument can be used not only to analyse and describe forms and qualities of cantonal democracies, but the values of the dimensions and ensuing democracy types can also be used as either dependent or explanatory variables. In reality, there are different approaches to explain institutional varieties of democracies in empirical democracy research. Based on Freitag and Vatter (2009), Lijphart (1999: 250ff.), Kaiser (1997: p. 422), or Vatter (2002: 414ff.) and taking into account the particular characteristics of the Swiss cantons, we examine two competing hypotheses (as well as a variation of one of these two) on what explains variation across Swiss cantonal democracies.

The first relies on the cultural commonality of political systems to explain the development of political institutional settings. Pursuant to this hypothesis, common cultural regions shape the understanding of democracy and are formative for the evaluation of different forms of democracy in the cantons. More

5 The factors were calculated in SPSS using the regression method on the basis of principal component analysis. Six of the 48 subcomponents were each further subdivided into two subsubcomponents which were then treated as latent variables.

6 A factorised aggregation strategy was considered as an alternative approach to estimate the subcomponents. From a democracy theory point of view the unequal loading of the conceptually equal components appears problematic especially when individual components (such as an analysed canton year) are completely excluded because they do not load onto the same factor. If those components were subsequently but nevertheless proportionately calculated, very similar results ultimately are produced, for example in the case of transparent and clearly interpretable averaging. 
specifically, subnational comparative democracy research commonly assumes that German-speaking cantons are characterized by radical and inclusive forms of citizen participation, while the Latin cantons ${ }^{7}$ more strongly follow the liberal, power-separating and representative democracy model of France. StadelmannSteffen and Freitag (2011: pp. 533-534) summarize this widespread position as follows: "The Swiss cantons offer an excellent opportunity to assess the relevance of the participatory-inclusive and representative-delegative logic of democracy" whereby the German-speaking cantons match the former democracy type and the French-speaking cantons the latter. According to Stadelmann-Steffen and Freitag (2011), one can expect that the regional language differences of the two ideal types of democracy theory correspond to our dual measurement model. Thus the first hypothesis posits that the Swiss-German cantons follow the radical democracy model while Latin cantons match the liberal one.

With regard to current research debate, at least one variation of the first hypothesis should equally be analysed: a regional language difference is also posited between specific dimensions of the two democracy models, and not only in relation to their entirety. Linder (2005: p. 272) for example observes that the culture of direct democracy is more strongly pronounced in German-speaking Switzerland while the French-speaking cantons and Ticino conform more to the basic model of "representative" democracy with little influence of direct democracy. Ladner (2007) likewise concludes that in the Latin regions of Switzerland, the idea of representative, electoral democracy with a comparatively high value placed on parliament is more developed than in German-speaking Switzerland, which is distinguished by highly developed instruments of direct democracy (cf. also Ladner 1991; Vatter 2002; Linder 2010). In our measuring concept, the following observations of specific dimensions can be made: The "participation" dimension of the radical model of democracy stands primarily for participative, direct-democratic structures while the "electoral accountability" dimension of the liberal model of democracy combines representative-democratic institutions in which both formal rules and constitutional reality are considered. On the basis of the posited regional language differences concerning the forms of direct and representative democracy, we thus also analyse whether the cantons in the individual language regions adopt specific characteristics in the "participation" and "electoral accountability" dimensions. According to Linder (2005), hypothesis $1 \mathrm{~B}$ is then defined as follows: Cantons in Latin Switzerland have higher values in the "electoral accountability" dimension and lower values in

7 Latin Switzerland comprises the seven cantons where the German-speaking population is a minority (Ticino, Fribourg, Vaud, Valais, Neuchâtel, Geneva, and Jura). 
the "participation" dimension, while German-speaking cantons display the opposite pattern.

The second approach to explaining democracy (types) presents an alternative to the prevailing "cultural-linguistic hypothesis." It relies on a central assumption of historical institutionalism that values institutional arrangements primarily as a legacy of earlier social debate but influential until this very day. The political "Erblast” hypothesis (Rose and Davis 1994) highlights the common historical background of state entities and the great inertia of regulations adopted much earlier. According to this approach, specific models of democratic techniques for conflict resolution are the result of common historical legacies and preceding constitutional traditions that possess great inertia. The historical continuity of political institutions is primarily traced back to formative historical periods that preclude alternative developments (Collier and Collier 1991). To analyse the political Erblast hypothesis we examine the influence of democratic constitutional movements between 1830 and 1870 on the models of cantonal democracy between 1979 and 2009. According to Kölz (2004: p. 42), the cantons can be divided into four groups on the basis of their historical constitutional movements in the course of the democratization process of the $19^{\text {th }}$ century. The first group is composed of cantons with a liberal-regenerative but no democratic movement. ${ }^{8}$ It includes the francophone and liberal-individualist thinking cantons Vaud, Geneva, and Neuchâtel, ${ }^{9}$ but also Lucerne and St. Gall. According to Kölz (2004: 43ff.), the second group is composed of the regenerative cantons with democratic movement, namely the Swiss-German cantons of Zurich, Berne, Solothurn, Basel-Country, Schaffhausen, Aargau, and Thurgau. The third group consists of the German-speaking Landsgemeinde cantons. With their longstanding direct-democratic, collective and pre-modern traditions, a liberal-regenerative movement was out of the question (Kölz 2004: 231ff.). The group includes Uri, Schwyz, Obwalden, Nidwalden, Glarus, Zug, Appenzell Inner- and Outer-Rhodes as well as Grisons. Finally, a fourth group consists of cantons with a special kind of constitutional development (Kölz 2004: 325ff.). Common characteristics of this last group are the strong position of conservatives, a late (if at all) and mostly weak liberal-regenerative movement, and the

8 While the liberal-regenerative movement fought primarily for individual freedoms, legal equality, separation of powers, and strong parliamentary government, democratic movements advocated the implementation of socio-political and egalitarian goals through the adoption and expansion of direct-democratic citizen rights (Kölz 2004).

9 Neuchâtel constitutes a special case within this group on the basis of its monarchical background. However, its first constitution of 1848 was a particularly pronounced example of a classic power-separating liberal-representative constitution (Kölz 2004). 
absence of a democratic movement. A prime example is Basel-City which had become a city-state due to a cantonal division. It was governed during the regenerative period by the so-called "Ratsherrenregiment" (Alderman regime) and had, until 1875, a restorative constitution with moderate conservative and individual liberal elements (Kölz 2004: p. 337). ${ }^{10}$ The conservative-catholic Frenchspeaking cantons of Fribourg and Valais also belong to this group. Of all the cantons, they most strongly resisted democratization and constitutional reform. Though Kölz (2004: 325ff.) describes Fribourg as a canton with a liberal constitution lacking in direct-democratic elements, he includes it in the fourth group due to the strong position of conservatives. ${ }^{11}$ Similarly, the liberal-conservative 1852 and 1875 constitutions of Valais are characterized by strong conservative-restorative elements and the absence of direct democracy. The only Italian-speaking canton is an exceptional case and likewise assigned to the fourth group. Ticino, shaped by much unrest, has a representative constitution in line with the FrenchHelvetian model (Kölz 2004: p. 330). A final exception is Jura, founded only in 1979. According to Kölz (2004: p. 467), the first constitution of Jura was unusual in that it directly referred to the 1789 French Declaration of Human Rights that explicitly guarantees classic-liberal freedoms, while at the same time meeting only the minimum of citizens' rights. If one summarizes Kölz's (2004) typology of cantonal constitutional movements with reference to both democracy models that are the main focus here, those cantons with liberal-regenerative but no democratic movement (group 1) as well as those with conservative-liberal constitutions and no democratic movement (group 4) more closely correspond to the liberal-democratic model. Meanwhile, the regenerative cantons with a democratic movement (group 2) as well as the Landsgemeinde cantons with longstanding direct-democratic traditions (group 3) would be assigned to the radical-democratic model. On a continuum of democracy forms from liberal to radical, the liberal-regenerative cantons without democracy movement and the Landsgemeinde cantons are positioned at either end, while the other two groups are closer to the middle.

A variation of the theory of path dependency just presented emphasizes the role of contemporary historical and political events (so-called "critical junctures;" see Pierson 2000) to explain the characteristic forms of democratic institutions. Specific decisions, encountered at particular critical turning points, can

10 In contrast to all other cantonal constitutions, the constitution of Basel-City does not contain any commitment to popular sovereignty.

11 Fribourg was the last Swiss canton to abandon representative democracy (Kölz 2004: p. 336). The popular election of the cantonal government, the legislative initiative and the optional legislative referendum were only introduced in 1921. 
thus lead to path changes and institutional reform that, although limited by context, redefine the logic of institutional regimes (Kaiser 2002). The hypothesis of critical junctures is best illustrated by the canton of Berne: the deep-seated crisis in the relationship with the canton's Jura region, the long-lasting and sometimes violent conflicts between separatist movements and those loyal to Berne, and the secession of the northern part of the Jura region that led to the creation of Jura canton in 1979, were, without a doubt, politically influential events for Berne. The financial scandal uncovered in the mid-1980s, in which the government of Berne had misused lottery money to financially support the "Force démocratique," a militant organization in Berne’s Jura region, likewise received a lot of attention. These extraordinary events subsequently led to a total revision of Berne's constitution, adopted in 1993. ${ }^{12}$ Even where no such momentous events occurred, total revisions of cantonal constitutions constitute important stages in the democratic development which combine the collective experiences of social and political change of the past decades and mould them into institutional reform. Therefore, in light of progressive phases of democracy in the past 100 years, one can assume that more recent reforms allow for larger-scale emancipatory participation demands of society. Accordingly, better democracy values can be anticipated the more recent a total revision of a cantonal constitution has taken place.

Ultimately, in the sense of a control hypothesis, additional socio-structural and socio-economic characteristics should be included for the explanation of political-institutional differences. On the basis of the obvious socio-economic and socio-structural heterogeneity between the cantons, this approach has been used for some time to explain political-administrative differences between the Swiss cantons (Geser and Höpflinger 1977: p. 132; Horber and Joye 1979). A common indicator is the percentage of workers employed in each of the three economic sectors. ${ }^{13}$

12 It was the first constitution to introduce the principle of public access within the cantonal administration, place particularly strong emphasis on government accountability, and give citizens the power of appointment and dismissal of government (Kölz 2004: p. 103).

13 We thank a reviewer of this article for suggestions of further possible control variables that we analysed in several regression models not presented here. Actually, neither the fact whether or not a canton had belonged to the "Sonderbund" (as an alternative variable for path dependency), additional variables to measure socio-structural heterogeneity (population density, percentage of Catholics), nor different geographical measurements (distance, proximity to France/Italy/ Germany) have any explanatory power. Moreover, these variables do not change the substantive results with respect to the variables that we have used. Because our analysis was constrained by a limited number of data, we have only used control variables with explanatory power in the following models. 


\section{Liberal and Radical Cantonal Democracies Compared}

A two-stage approach was chosen for the empirical analysis. In the first stage, the values of each individual canton are displayed on a democracy map. In doing so we used the mean z-transformed values for both the radical and liberal democracy forms and both dimensions (radical participation and electoral accountability) over the whole time period (1979-2009). The horizontal axis represents the form of radical democracy (Figure 1) and the "radical participation" dimension (Figure 2), while the values for liberal democracy (Figure 1) and "electoral accountability" (Figure 2) are shown on the vertical axis. In the second stage, the hypotheses were tested using multivariate regression analyses.

Figure 1 positions the cantons within a two-dimensional field of liberal and radical democracies. It shows clusters of cantons that have both linguistic-cultural and constitutional-historical similarities. Thus the French-speaking cantons (VD,

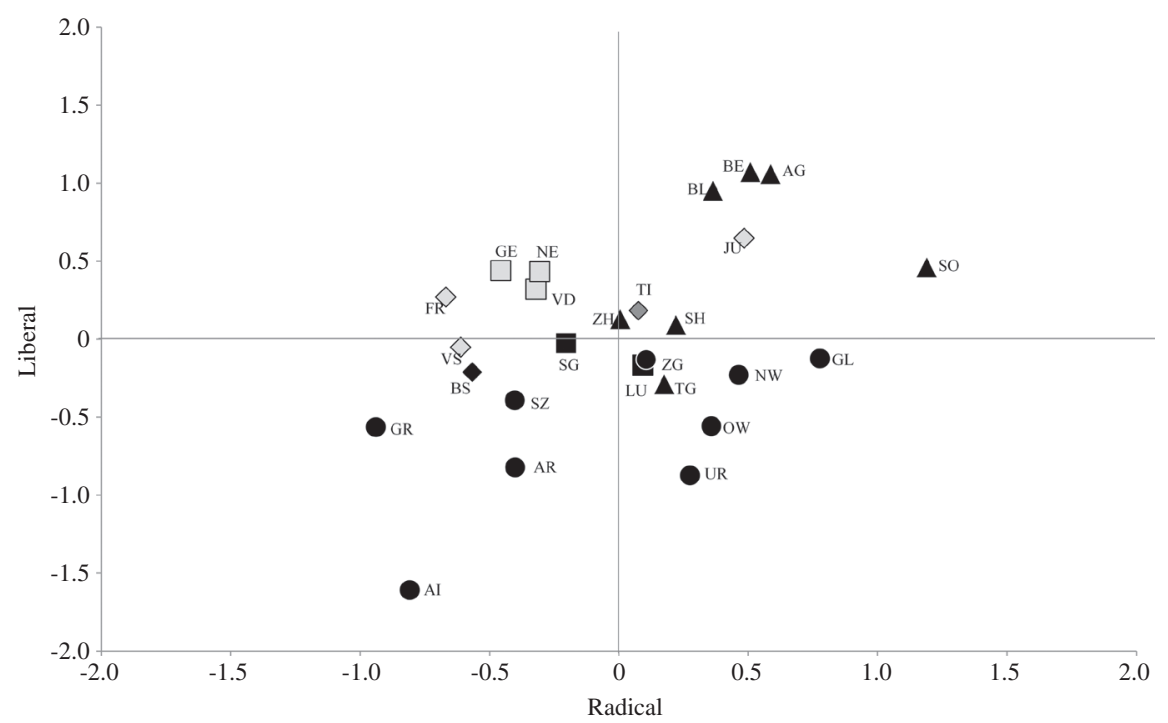

Figure 1: Conceptual Map of Cantonal Democracies along the Liberal and Radical Democracy Axes.

Explanation: Light grey: predominantly French-speaking cantons; grey: Ticino (TI); black: predominantly German-speaking cantons; the groups according to Kölz (2004): square: cantons with liberal regenerative movement but no democratic movement (VD, GE,NE, LU, SG); triangle: regenerative cantons with democratic movement (ZH, BE, SO, BL, SH, AG, TG); circle: Landsgemeinde cantons (UR, SZ, AI, AR, OW, NW, GL, ZG, GR); diamond: cantons with special constitutional development (BS, FR, VS, TI, JU). 
GE, and NE), characterized by a strong liberal-regenerative movement in the mid$19^{\text {th }}$ century and the absence of a democratic movement, are located as expected in the first quadrant of above-average liberal-representative but rather weak radical-democratic democracies. The two Swiss-German cantons that belong to this constitutional-historical group (LU and SG) stand out due to their comparably stronger radical-democratic but weaker liberal components.

The cantons with a liberal and a democratic constitutional movement - all of them Swiss-German cantons (ZH, BE, SO, BL, SH, AG and TG) - are located in the second quadrant of above-average liberal and radical democracies, with the exception of Thurgau, which lies just under the liberal mean. The third group of (former) Landsgemeinde cantons from German-speaking Switzerland (UR, SZ, OW, NW, GL, ZG, AR, AI and GR) are distributed over the third and fourth quadrants. These cantons all have below-average liberal democracy values. The fourth group of former catholic-conservative cantons with no liberal and democratic regenerative movement (BS, FR, VS, TI and JU) is characterized by heterogeneity. On the one hand, there are cantons with low radical-democratic and only average liberal components (FR, VS and BS). What is noticeable is that linguistic affiliation does not play a role here and the German-speaking, mixed language and French-speaking cantons in this group are all located close together. On the other hand, the same does not apply to the other two cantons in this group (TI and JU): The only Italian-speaking canton, Ticino, adopts average values on both axes and (together with Zurich) best approximates the Swiss mean. Deserving special mention is Jura, which is located within the group of liberal cantons with democratic movement and therefore very close to its former home canton, Berne.

Figure 2, with the axes "electoral accountability" and "radical participation," displays only one typical dimension each of the two central democracy models. It emphasizes the important influence of $19^{\text {th }}$ century constitutional-historical movements on cantonal democracy models at the turn of the $21^{\text {st }}$ century: the participatory elements of Swiss-German and Swiss-French cantons with no democratic-constitutional movement are still below average. (Former) Landsgemeinde cantons are still located in the lower-right quadrant, characterized by poor electoral accountability relationships but high direct-democratic participation. Conversely, cantons which had strong liberal and democratic movements now have both strong electoral accountability and highly-developed direct-democratic forms of participation.

Furthermore, Figure 2 clearly shows that not all Swiss-German cantons are located together in the lower-right quadrant, but only the rural Central and Eastern cantons. These cantons provide their citizens with strong participation rights that are also more intensively used. The remaining Swiss-German cantons are divided across the other three quadrants, not conforming to the hypothesis of linguistic-regional 


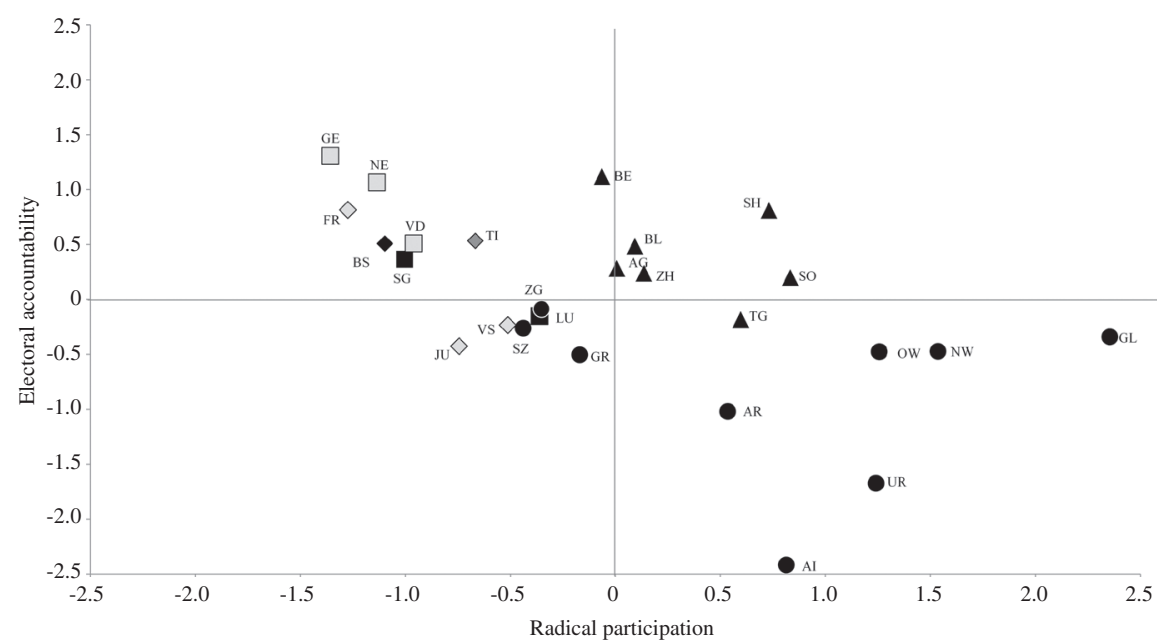

Figure 2: Conceptual Map of Cantonal Democracies upon Two Dimensions of The Democracy Models (electoral accountability and radical participation).

Explanation: Light grey: predominantly French-speaking cantons; grey: Ticino (TI); black: predominantly German-speaking cantons; the groups according to Kölz (2004): square: cantons with liberal regenerative movement but no democratic movement (VD, GE, NE, LU, SG); triangle: regenerative cantons with democratic movement (ZH, BE, SO, BL, SH, AG, TG); circle: Landsgemeinde cantons (UR, SZ, AI, AR, OW, NW, GL, ZG, GR); diamond: cantons with special constitutional development (BS, FR, VS, TI, JU).

differences. As for St. Gall and Basel-City, they sit together with the Latin cantons because they too have higher values for electoral accountability and comparatively lower values for participation. Likewise, and again contrary to the linguistic-cultural hypothesis, the (predominantly) French-speaking cantons of Valais and Jura are both located in the lower-left quadrant. They not only have the expected low values for participation, but also below average values for electoral controls. Zug, Lucerne, Grisons and Schwyz are also in this quadrant, as they have (below) average values on both dimensions. Finally, Basel-Country, Zurich, Aargau, Schaffhausen and Solothurn are located in the upper-right quadrant. They have high participation values and emphasize accountability and control of political representatives.

From Figure 2, one can thus interpret the following: the lower a canton's value in the "participation" dimension, the higher its values for electoral accountability (Pearson's $r=-0.55)$. This indicates that both dimensions are mutually exclusive to a certain degree: a cantonal democracy emphasizes the accountability of political representatives and control of the elite either through elections or with direct-democratic referendums on specific issues. However, this connection can definitely not be explained by language alone. 
In a final empirical step we examine the hypotheses using multivariate regression models. The average values for liberal and radical democracy between 1979 and 2009 and for the electoral accountability and participation dimensions serve as dependent variables. Alongside language ${ }^{14}$ and controls (age of constitution, ${ }^{15}$ primary sector ${ }^{16}$ ) as independent variables, the affiliation of the canton to the four groups of constitutional-historical movements is modelled as a categorical variable (four dummy variables).

The regression analysis to a large extent confirms the results observed in Figures 1 and 2 (Table 2). Noticeable is the relevance of constitutional-historical movements for the current democracy positions of the cantons. The typology of constitutional movements according to Kölz (2004) is proven to be explanatory both for the development of cantonal liberal democracy and for the "electoral accountability" and "radical participation" dimensions. The linguistic-cultural hypothesis on the other hand has only partial explanatory power: though the French-speaking cantons have significantly higher liberal democracy values, there are no linguistic-cultural differences in the radical democracy model, nor in the two dimensions. The date of the most recent full revision of the cantonal constitution is significant for the position of cantons on the radical democracy axis: proximity in time of the revision corresponds to higher values on the radical democracy axis. This indicates that the radical democracy dimension measures not only different forms of citizen participation, but also current emancipatory demands of citizens and, in this way, is an expression of the present modernity of cantonal democracies. In this sense the explanatory power of the age of the constitution can also be interpreted for the values of the liberal model and the participation dimension: the younger a cantonal constitution, the higher the values for both. Finally, the other significant control variable (which measures the share of employment in the primary sector) confirms the observation from Figures 1 and 2 that it is the generally rural Landsgemeinde cantons that are characterized by below-average liberal values and low electoral controls.

\section{Conclusions}

The present study has attempted to empirically measure the multi-dimensional quality of democracy in the Swiss cantons on the basis of comprehensive data

14 This variable measures the proportion of French-speakers in a canton.

15 The age of the constitution is determined by the average number of years since the introduction of the last constitution (between 1979 and 2009).

16 This variable measures the primary-sector share of employment in a canton (agriculture etc.). 


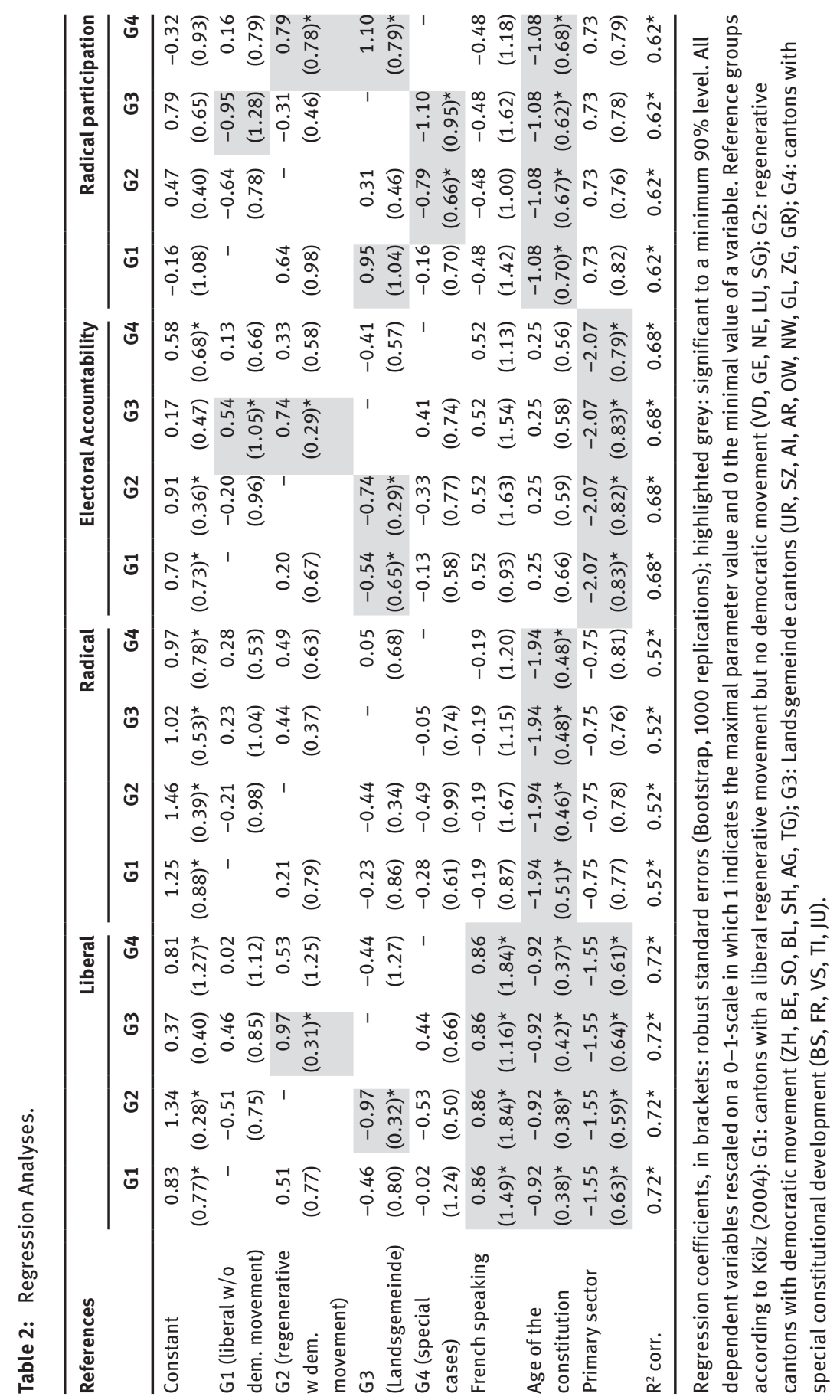


and by using liberal-representative and radical-participatory democracy models as a conceptual basis. The political Erblast hypothesis, which points to a significant role of $19^{\text {th }}$ century constitutional movements for contemporary forms of cantonal democracies, was tested as an alternative explanation to the widespread linguistic-cultural hypothesis of clear democracy-typical differences between Latin and German-speaking Switzerland.

By looking at the distribution of cantons on the graphs Figures 1 and 2, it is clear that there is a strong formation of groups of German-speaking and Latin democracy patterns, although there are important exceptions. The francophone cantons are, for the most part, located together in the quadrant of strong liberalrepresentative democracies. Basel-City and St. Gall are important exceptions, since they are also located in this quadrant but are German-speaking. The radical-democratic but least liberal Landsgemeinde cantons of Central and Eastern Switzerland are located on the opposite side of the graph. Finally, the North-Western German-speaking cantons have both high radical- and liberal-democratic characteristics. The grouping of francophone cantons in the liberal-representative first quadrant, the positioning of the German-speaking Mittelland cantons in the second quadrant, and the distribution of the (former) Landsgemeinde cantons in the third and fourth quadrants all suggest a limited significance of specific linguistic and regional neighbor cultures. Notably the positions of BaselCity, St. Gall, Jura, Valais, and Ticino, but also the heterogeneity of the SwissGerman cantons, speak against an oversimplified parallel of linguistic-cultural and democracy characteristics.

Does the alternative approach that institutional arrangements are considered primarily as the result of common historical legacies and past constitutional traditions offer a more profitable explanation than the widespread linguisticcultural hypothesis? The individual positions of the cantons certainly show that the presented cantonal democracy patterns between 1979 and 2009 directly correspond to the particular direction of cantonal constitutional movements between 1830 and the 1870 s. $^{17}$

Thus, the cantons of Geneva, Valais and Neuchâtel have above-average high values on the liberal-representative axis that clearly correspond to the strong position of their liberal-regenerative movements (and the simultaneous lack of a democratic movement) in the first half of the $19^{\text {th }}$ century. Similarly, the liberalregenerative cantons with a strong democratic movement form their own group, characterized by both high liberal- and high radical-democratic values; they

17 The regression analyses also indicate that the date of a complete revision of a cantonal constitution plays an important role: the more recent the last revision of the constitution, the greater the inclusion of radical-democratic and emancipatory demands. 
thereby most closely resemble the ideal form of modern democracy. This approach also explains why the Swiss-German cantons of Basel-City, St. Gall and (partially) Lucerne are positioned within the group of liberal-representative Latin cantons. The unusual lack of a strong democratic movement in the medium-sized and large Swiss-German cantons (i.e. non-Landsgemeinde cantons) in the mid-19 $9^{\text {th }}$ century is clearly reflected in the current democracy structures of these three cantons. This approach also provides an explanation for the low liberal and participatory democracy values for Valais, reflecting the dominant conservative-catholic forces of the last century that gave rise to neither a strong liberal nor a democratic movement. Finally, it can be observed that all (former) Landsgemeinde cantons are located below the liberal democracy axis. Referring to Figure 2 (electoral accountability vs. radical participation) in particular, a further differentiation within this group can be made. The three cantons located in the fourth quadrant (GR, SZ and ZG) with below-average values on both dimensions are not only those in which the assembly traditions lasted the shortest amount of time (dissolved in 1848 at the latest), but they are also those with the strongest regional conflicts (Outer- vs. Inner-Schwyz, Zug city vs. countryside, three Leagues and languages in Grisons). Conversely, the other (former) Landsgemeinde cantons in the third quadrant have had no comparable internal conflicts and the (pre-modern) Landsgemeinde traditions have been retained also post-1848. Table 3 is a summary of the classification of present-day forms of democracy with their corresponding development of different $19^{\text {th }}$ century constitutional movements and forms.

Overall, then, constitutional-historical legacies and the strength of $19^{\text {th }}$ century social movements deliver a more persuasive explanation for the present forms of cantonal democracies than the widespread linguistic-cultural hypothesis. These

Table 3: Classification of Current Cantonal Democracy Types on the Basis of Their Constitutional Movements.

\begin{tabular}{|c|c|c|}
\hline & Weak radical democracy & Strong radical democracy \\
\hline & $\begin{array}{l}\text { (low values of radical } \\
\text { participation) }\end{array}$ & $\begin{array}{l}\text { (high values of radical } \\
\text { participation) }\end{array}$ \\
\hline $\begin{array}{l}\text { Strong liberal } \\
\text { democracy (high } \\
\text { values of electoral } \\
\text { accountability) }\end{array}$ & $\begin{array}{l}\text { - Liberal-regenerative cantons } \\
\text { without democratic movement } \\
\text { - Conservative cantons without } \\
\text { regenerative movement }\end{array}$ & $\begin{array}{l}\text { - Liberal-regenerative } \\
\text { cantons with democratic } \\
\text { movement }\end{array}$ \\
\hline $\begin{array}{l}\text { Weak liberal democracy } \\
\text { (low values of electoral } \\
\text { accountability) }\end{array}$ & $\begin{array}{l}\text { - Former Landsgemeinde } \\
\text { cantons (before 1848) with } \\
\text { strong regional conflicts }\end{array}$ & $\begin{array}{l}\text { - (Former) Landsgemeinde } \\
\text { cantons (after 1848) without } \\
\text { regional conflicts }\end{array}$ \\
\hline
\end{tabular}


results make it clear that the dominant hypothesis of the dichotomy between direct-democratic German-speaking Switzerland and representative-democratic French-speaking Switzerland is too narrow. Rather, the main types of $19^{\text {th }}$ century constitutional movement according to Kölz (2004) are still quite united forms of democracy and confirm the inertia of political institutions.

\title{
Appendix: Short definitions of the indicators used
}

\author{
Liberal Dimensions
}

\begin{tabular}{|c|c|}
\hline \multicolumn{2}{|c|}{ Liberal Constitutionalism } \\
\hline \multicolumn{2}{|c|}{ Individual freedom } \\
\hline \multicolumn{2}{|c|}{ Freedom rights } \\
\hline kv_frr_priva & Constitutionally guaranteed protection of the privacy sphere \\
\hline kv_frr_dign & Constitutionally guaranteed protection of human \\
\hline kv_frr_life & Constitutionally guaranteed right to life, physical and psychic integrity \\
\hline kv_frr_info & Constitutionally guaranteed freedom of information \\
\hline kv_frr_data & $\begin{array}{l}\text { Constitutionally guaranteed protection against misuse of personal } \\
\text { data }\end{array}$ \\
\hline kv_frr_mov & Constitutionally guaranteed freedom of movement \\
\hline kv_frr_sciart & $\begin{array}{l}\text { Constitutionally guaranteed right to academic freedom and freedom } \\
\text { of art }\end{array}$ \\
\hline kv_frr_fam & Constitutionally guaranteed right to marry and to found a family \\
\hline kv_frr_opin & $\begin{array}{l}\text { Constitutionally guaranteed freedom of opinion (building, uttering, } \\
\text { propagating, and receiving) }\end{array}$ \\
\hline kv_frr_bel & Constitutionally guaranteed freedom of faith, conscience and creed \\
\hline \multicolumn{2}{|l|}{ Property rights } \\
\hline kv_frr_home & Constitutionally guaranteed protection of the sanctities of the home \\
\hline kv_frr_est & Constitutionally guaranteed freedom of establishment \\
\hline kv_frr_prop & Constitutionally guaranteed protection of property \\
\hline kv_frr_econ & Constitutionally guaranteed freedom of trade and occupational choice \\
\hline kv_frr_expro & Constitutionally guaranteed restrictions to expropriation \\
\hline \multicolumn{2}{|c|}{ Acceptance of laws and regulations } \\
\hline kv_grr_rel & $\begin{array}{l}\text { Constitutionally codified duty to respect the rights of others when } \\
\text { exercising one's own basic liberties }\end{array}$ \\
\hline kv_legdut & $\begin{array}{l}\text { Explicit constitutional codification of everybody's obligation to comply } \\
\text { with his legal duties }\end{array}$ \\
\hline kv_ordsec & $\begin{array}{l}\text { Constitutional codification of the state's responsibility to protect the } \\
\text { public security and order }\end{array}$ \\
\hline crime_rate_N & $\begin{array}{l}\text { Number of convictions under the penal law, per } 1000 \text { inhabitants } \\
\text { (inverse) }\end{array}$ \\
\hline
\end{tabular}




\section{(Liberal Dimensions Continued)}

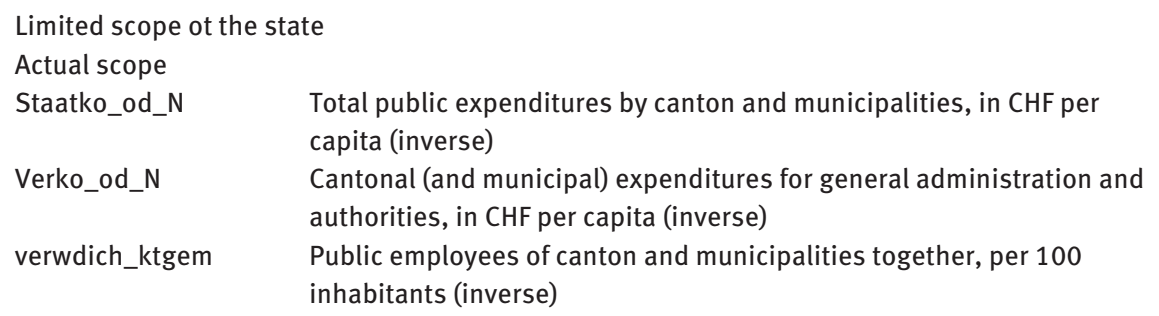

Constitutional provisions

kv_check Cons_tion

Constitutional codification of a continuous assessment of public tasks

kv_budlim Constitutional codification of the principles of an economical and balanced budget management of the state

kv_finvorb Constitutional codification of conditional financing before adopting new public tasks

kv_taxhurd Constitutional codification of institutional barriers for tax increases

Rule of law

Supremacy of the law

Formal supremacy of the law

\begin{tabular}{|c|c|}
\hline kv_pr_hear & Constitutional codification of a right to a court hearing \\
\hline kv_gesvorb & Constitutional codification of legal proviso \\
\hline kv_retroban & Constitutional codification of the prohibition on retroactive legislation \\
\hline kv_pr_judgm & $\begin{array}{l}\text { Constitutional codification of a right for justified court ruling and } \\
\text { instruction on the right to appeal }\end{array}$ \\
\hline kv_willkverb & Constitutional codification of the prohibition of arbitrariness \\
\hline
\end{tabular}

Substantive supremacy of the law

$\begin{array}{ll}\begin{array}{l}\text { kv_grr_restr } \\ \text { kv_grrkern }\end{array} & \begin{array}{l}\text { Constitutional restrictions of curtailing basic rights } \\ \text { Constitutional codification of the inviolability of the core of basic } \\ \text { rights } \\ \text { Cv_grrbind }\end{array} \\ \begin{array}{l}\text { Constitutional codification the commitment of public power and } \\ \text { individuals to the basic rights }\end{array} \\ \text { kv_pr_fair } & \begin{array}{l}\text { Constitutional codification of the right for a fair (/and equal) treatment } \\ \text { in court hearings }\end{array} \\ \text { kv_gratadvice } & \begin{array}{l}\text { Constitutional codification of the right for a free legal advice } \\ \text { Constitutional codification of the right of deprived people for free legal } \\ \text { assistance and legal aid }\end{array} \\ \text { kv_diskrverb } & \begin{array}{l}\text { Explicit constitutional prohibition of discriminating/benefitting certain } \\ \text { groups with regard to the equality before the law } \\ \text { Explicit constitutional codification of a general equality before the law }\end{array}\end{array}$

Protection of minorities

Voting behavior favoring minorities

MF_Frauen Minority-friendliness of cantonal voting results at national polls regarding women 


\section{(Liberal Dimensions Continued)}

\begin{tabular}{|c|c|}
\hline MF_Sprachmind & $\begin{array}{l}\text { Minority-friendliness of cantonal voting results at national polls } \\
\text { regarding language minorities }\end{array}$ \\
\hline MF_Alte & $\begin{array}{l}\text { Minority-friendliness of cantonal voting results at national polls } \\
\text { regarding elderly people }\end{array}$ \\
\hline MF_Behinderte & $\begin{array}{l}\text { Minority-friendliness of cantonal voting results at national polls } \\
\text { regarding handicapped people }\end{array}$ \\
\hline MF_Auslaend & $\begin{array}{l}\text { Minority-friendliness of cantonal voting results at national polls } \\
\text { regarding foreigners }\end{array}$ \\
\hline MF_Militaerverw & $\begin{array}{l}\text { Minority-friendliness of cantonal voting results at national polls } \\
\text { regarding deniers of military service }\end{array}$ \\
\hline MF_Junge_Stim & $\begin{array}{l}\text { Minority-friendliness of cantonal voting results at national polls } \\
\text { regarding the voting right of younger people }\end{array}$ \\
\hline \multicolumn{2}{|c|}{ Consitutional provisions } \\
\hline kv_frr_lang & Constitutional guarantee of language freedom \\
\hline kv_minprot & Constitutional codification of the protection of the rights of minorities \\
\hline kv_frr_cohab & Constitutional guarantee of the freedom of the form of cohabitation \\
\hline
\end{tabular}

Strength of parliament versus government

Independence

Eröffnung_N Opening of the new legislature period by government (inverse)

Parlamentsdienst Independent parliamentary secretariat resp. later parliamentary services

Id_Unver Incompatibility of governmentary and parliamentary mandate

Supervisory powers

Akteneinsicht_Au Insight in files by inspection commissions

Inforecht Information right of members of parliament explicitly codified

Akteneinsicht_all Inquiry and insight in files by general commissions

PUK Possibility of inserting a (powerfull) parliamentary fact finding commission legally provided

Konfliktregelung Final decision-making competence in case of conflict between member of parliament and government

Legislative powers

Legislative competencies of parliament

Reg_programm Parliament treats government program

Parllnit Possibility of parliamentary initiative

Fragestunde Possiblity of question time

Legislative competencies of government

Finanzbefugnisse Financial competences of government (inverse)

Dringlichkeitsrec Right of urgent acts by government (invers)

Notrecht_N Right in state of emergency by government (inverse) 


\section{(Liberal Dimensions Continued)}

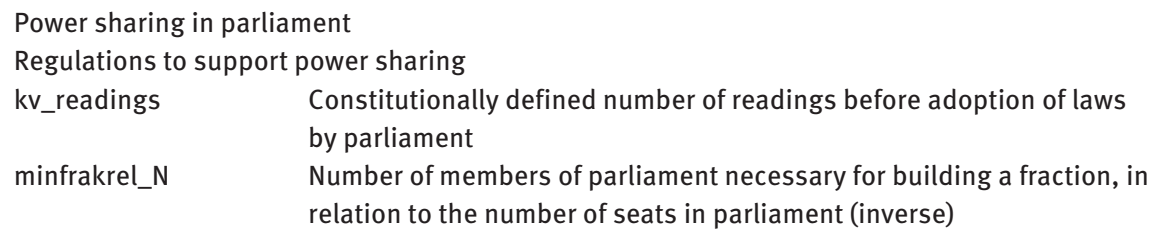

Strength of the opposition

Oppositionsstaerk Index of effective power of opposition parties versus governing parties in parliament (seat shares)

CoalitType2 Coalition type of government (minority, surplus majority, minimal winning, hegemonial)

Judicial independence

Separation from executive and legislature

Unvereinbar_KR Incompatibility of mandate at the cantonal high court with parliamentary mandate

Funktionelle Una Independence of courts/jurisdiction codified in constitution or law

Unvereinbar_RR Incompatibility of mandate at the cantonal high court with government mandate

Personal independence

Unvereinbar_An Incompatibility of mandate at the cantonal high court with mandate as advocate

Präsidentenwahl Instance for confirming resp. electing the president of the cantonal high court

Unvereinbar_VR Incompatibility of mandate at the cantonal high court with an administrative board mandate

Amtsdauer Term of office of judges at the cantonal high court

Amtszeitbeschrän Limitation of term of office at the cantonal high court (inverse)

Professionalization

Eignungsprüfung Instance for controlling ability and eligibility of candidates for the cantonal high court

Wahlvorbereitung Instance preparing elections

Aufsichtsorgan Instance of superintendence

Organizational independence

Budgetrecht Courts are sovereign in budgetary matters

Verwaltungsauto Constitutionally or legally codified right of autonomous administration of courts or jurisdiction

Antragsrecht_Parl Right for applying for finances directly at the parliament

Anstellung_Kanzl Appointment of chancellery by highest cantonal court

Independent controlling instances

Administrative jurisdiction

Verwaltungsgeric Administrative court as ultimate authority in disputes concerning administrative law 


\section{(Liberal Dimensions Continued)}

\begin{tabular}{ll}
\hline $\begin{array}{l}\text { Generalklausel } \\
\text { VerwaltungsG_a } \\
\text { Rechtsweggaranti }\end{array}$ & $\begin{array}{l}\text { Efficacy of administrative court } \\
\text { Years since introduction of an administrative court } \\
\text { Guaranteed recourse to the cantonal courts also in cases concerning } \\
\text { federal administrative law }\end{array}$ \\
$\begin{array}{ll}\text { Constitutional review } \\
\text { Verfassungsgeric }\end{array}$ & $\begin{array}{l}\text { Institutionalized constitutional court } \\
\text { Index of powers of courts regarding constitutional review }\end{array}$ \\
$\begin{array}{ll}\text { VerfG_Index } & \text { Existence of a cantonal ombudsman } \\
\text { Independent supervisory authorities } \\
\text { Ombuds } & \text { Scope of financial control } \\
\text { FK_Umfang } & \text { Constitutionally guaranteed independence of financial control } \\
\text { kv_fincont } & \end{array}$ \\
\hline Electoral accountability
\end{tabular}

Secret elections

Free, secret, and regular elections

secelec_parl Secret ballot at elections of cantonal parliament

secelec_reg Secret ballot at elections of cantonal government

Competition

Electoral vulnerability in government

CompRegElec2 Difference between number of candidates and number of mandates in last total renewal elections

Kampfwahl_Reg More candidates than seats in last total renewal elections

wett_reg_se $\quad 100 \%$ minus seat share of strongest party in government

Electoral vulnerability in parliament

wett_parl2_se_N Difference between largest and second largest party in parliament, in $\%$ of all seats (inverse)

wett_parl_se $\quad 100 \%$ minus seat share of strongest party in parliament

Electoral availability

Electorate's readiness to change their party vote

Volatilitaet_se_ye Parliamentary volatility: Netto change of seat shares of parties, standardized for the length of legislature

reg_stab2 Change in party composition of government

Clarity of governmental responsibility

Clarity of governmental responsibility

reg_party_N Number of governing parties (inverse)

spann_N Range of party composition of governing coalition (inverse)

Governmental autonomy

Independence from the people between elections

reglegisl Term of office of government, in years

parlegisl Term of office in parliament, in years

Referendumsauss No subsequent referendum possible in case of urgent acts, according to constitution 


\section{(Liberal Dimensions Continued)}

$\begin{aligned} & \text { Independence from specific interests } \\ & \text { kv_transpint }\end{aligned}$
$\begin{aligned} & \text { Constitutional codification of an obligation of members of parliament } \\ & \text { to disclose interest bonds } \\ & \text { kv_freemand }\end{aligned}$
$\begin{aligned} & \text { Constitutional codification of a free mandate for members of } \\ & \text { parliament }\end{aligned}$

Autonomy from other state levels

transfer_N Total revenues received from the federal state, in CHF per capita (inverse)

gem_init_ref2_N Right of initiative and referendum for single municipalities on cantonal laws (inverse)

Radical Dimensions

\section{Radical Participation}

Extended electoral rights

Direct popular elections

volkwahl Years gone by since the introduction of direct popular election of cantonal executive

regpraes_volkwa Election of the executive's president in popular elections

Ernennungsbehör Popular elections for the judges of the highest cantonal court

beratung_wahl Institutionalized opportunitiy for the citizens to collectively deliberate on elections and candidates

Possibility of recall

recall_reg Possibility to recall the cantonal executive from office ahead of time by a popular initiative

recall_parl_Possibility to recall the cantonal parliament from office ahead of time by a popular initiative

Direct democracy competencies

Rights of initiative and referendum

GIR Index for the institutional openness of the popular statutory initiative, as proposed by Stutzer (1999)

VIR Index for the institutional openness of the popular constitutional initiative, as proposed by Stutzer (1999)

GRR Index for the institutional openness of the statutory referendum, as proposed by Stutzer (1999)

FRR Index for the institutional openness of the fiscal referendum, as proposed by Stutzer (1999)

Other direct democracy instruments

verfahrinit_scope Existence and scope of a popular right to propose a different order of votes, postponement of authorities' projects, and/or revision of such projects 


\section{(Radical Dimensions Continued)}

\begin{tabular}{ll}
\hline beratung_sach & $\begin{array}{l}\text { Institutionalized opportunitiy for the citizens to collectively deliberate } \\
\text { on the issues put to popular vote } \\
\text { Index for the existence and institutional openness of the "constructive } \\
\text { KRR } \\
\text { referendum" }\end{array}$
\end{tabular}

Use of direct democracy competencies

Frequent ballots

Initot Number of popular initiatives put to vote

Reftot Number of referendums put to vote

Local self-government

Financial and perceived municipal autonomy

foed_tax_N Size of municipal as compared to cantonal fiscal revenues

foed_schreiber Degree of local autonomy as perceieved and reported by the heads of municipal administrations

Constitutional municipal autonomy

kv_gembest Constitutionally guaranteed right for the existing municipalities to continued existence

kv_gemaut Constitutional codification of municipal autonomy

kv_gemfusion Constitutional provisions concerning mergers of municipalities

Public accountability

Transparency of political processes

Transparency of parliament and communication by authorities

kv_vernehml Explicit constitutional codification of the mechanism of consultation

oeffprinz Legal enactment of the general rule that any governmental documents are freely accessible to the public

kv_behinfo Constitutionally codified duty of the authorities to inform the public about their activities

ParlSecretSess_N Provisions concerning the possibility of secret sessions or secret decisions on single agenda items by the parliament (inverse)

ParlProt Accessibility and elaborateness of the minutes of parliamentary sessions

Transparency of government and courts

kv_publger Constitutional provisions concerning the public access to judicial proceedings

kv_publreg Constitutional provisions concerning the public access to government sessions

Media

Legal frameworks for the media

kv_infodiv Constitutionally codified public task to promote information diversity

kv_zensverb Constitutional codification of the prohibition of censorship

kv_medfoerd Constitutionally codified public task to promote media access 


\section{(Radical Dimensions Continued)}

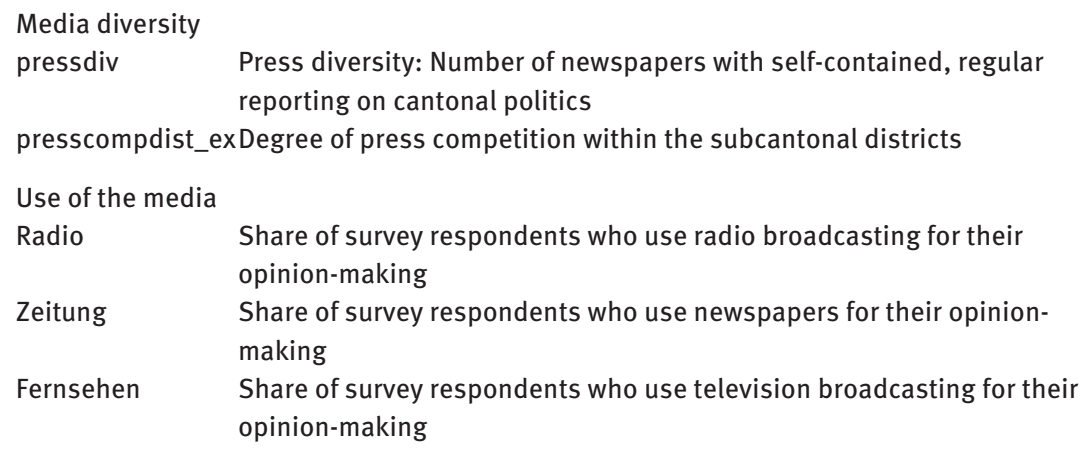

Extra-institutional participation

Constitutional protection of extra-institutional participation

kv_frr_demo Constitutionally guaranteed freedom to demonstrate

kv_frr_pet Constitutionally guaranteed right to petition

kv_frr_stri Constitutionally guaranteed right to strike

kv_frr_assoc Constitutionally guaranteed freedom of association

Participatory culture

Mitglied Share of survey respondents who are member of at least one political or economic organization

Leserbriefe Share of survey respondents who use letters to the editor for their opinion-making

Interesse Share of survey respondents who state to be very interested in politics

Inclusion

Equal political involvement

Universal suffrage

stimmalterakt Age required for the right to vote and to elect (inverse)

passelmin_go_N Age required for the right to be elected into the cantonal executive (inverse)

lady1 Female suffrage

Ausl_StiR Existence and scope of suffrage for foreign residents

Equal use of voting rights

T_Bildung_N Disproportionality of actual participation rates between groups of different education levels (inverse)

T_Qualifikation_N Disproportionality of actual participation rates between groups of different occupational statuses (invers)

turnout_v Turnout rate in cantonal popular votes

T_Geschlecht_N Disproportionality of actual participation rates between gender groups (inverse)

Minimal resources

Social rights

kv_sr_work Constitutionally guaranteed right to paid work 


\section{(Radical Dimensions Continued)}

\begin{tabular}{ll}
\hline kv_sr_dwell & $\begin{array}{l}\text { Constitutionally guaranteed right to housing } \\
\text { kv_sr_matmin }\end{array}$ \\
Constitutionally guaranteed rights to a minimal amount of material \\
resources, in case of need to be provided by public funds \\
Constitutionally guaranteed rights to the protection and advancement of \\
one's health
\end{tabular}

Rights to education

kv_sr_edurights

kv_sr_eduquant

Constitutionally guaranteed right to (adequate) education

Constitutionally codified public task to provide several educational services

kv_sr_eduacc Constitutionally guaranteed right to an equal and easy access to the educational services

kv_sr_edugrat Constitutionally guaranteed right to education free of charge

Inclusive representation

Minority-friendly electoral system

thresho_N Effective threshold to get a seat in the cantonal parliament (inverse)

proporz3reg Degree of proportionality of the electoral systems for parliamentary and governmental elections

parlmand Number of seats in the cantonal parliament

Representation of parties in parliament

rae Rae index of parliamentary party fractionalization

Gallagher_N Index for the effective disproportionality of the parliamentary electoral system, as proposed by Gallagher (inverse)

Voluntary proportional representation

reg_konk Cumulated vote share (in parliamentary elections) of all parties represented in government

kommprop Average number of seats in parliamentary committees per party

Proportional representation of socio-structural groups

Proportional representation by gender

Frauenteil_gov Share of female members in government

Frauenteil_parl Share of female members in parliament

Proportional representation by age and profession

Durchschnittsalte Average age of the members of government and parliament (inverse)

disrep_prof_reg_. Disproportionality of the occupational groups' representation in government and parliament (inverse)

\section{References}

Altman, David (2013). "Bringing Direct Democracy Back In: Toward A Three-Dimensional Measure of Democracy,” Democratization, 20(4):615-641. 
Altman, David and Aníbal Pérez-Liñan (2002). “Assessing The Quality of Democracy: Freedom, Competitiveness and Participation in Eighteen Latin American Countries," Democratization, 9(2):85-100.

Arato, Andrew (2006) "Accountability and Civil Society." In: (Peruzzotti, Enrique und Catalina Smulovitz. Hrsg.) Enforcing The Rule of Law: Social Accountability in The New Latin American Democracies. Pittsburgh: University of Pittsburgh Press, pp. 307-321.

Barber, Benjamin R. (1984) Strong Democracy. Participatory Politics for a New Age. Berkeley: University of California Press.

Bartolini, Stefano (1999) “Collusion, Competition and Democracy: Part I," Journal of Theoretical Politics, 11(4):435-470.

Bartolini, Stefano (2000) “Collusion, Competition and Democracy: Part II," Journal of Theoretical Politics, 12(1):33-65.

Beetham, David (1994) Defining and Measuring Democracy. London: Sage.

Beetham, David and Kevin Boyle (1995) Introducing Democracy. 80 Questions and Answers. Paris: Unesco.

Beetham, David (2004). "Freedom as The Foundation," Journal of Democracy, 15(4):61-75.

Bentham, Jeremy (1843 [1831]) “Constitutional Code. Book I.," In: (John Bowring, ed.) The Works of Jeremy Bentham. Edinburgh: W. Tait.

Bentham, Jeremy. (1960 [1776]) Fragment on Government. Harrison, Wilfrid. ed. Oxford: Blackwell.

Bollen, Kenneth A. (1989) Structural Equations with Latent Variables. Wiley Series in Probability and Mathematical Statistics. New York: Wiley.

Bühlmann, Marc, Wolfgang Merkel, Lisa Müller and Bernhard Wessels (2008) “Wie lässt sich Demokratie am besten messen? Zum Forumsbeitrag von Thomas Müller und Susanne Pickel," Politische Vierteljahresschrift 49(1):114-122.

Bühlmann, Marc, Sarah Nicolet and Peter Selb (2009a) "National Elections in Switzerland. An Introduction," Swiss Political Science Review 12(4):1-12.

Bühlmann, Marc, Adrian Vatter, Oliver Dlabac and Hans-Peter Schaub (2009b) “Demokratiequalität im subnationalen Labor: Anmerkungen zum Beitrag von Sabine Kropp u.a. in Heft 4/2008 der ZParl," Zeitschrift fur Parlamentsfragen 40(2):454-467.

Bühlmann, Marc, Wolfgang Merkel, Lisa Müller and Bernhard Wessels (2012a) “The Democracy Barometer. A New Instrument for Measuring the Quality of Democracy and Its Potential for Comparative Research," European Political Science, 11(1):519-539.

Bühlmann, Marc, Wolfgang Merkel, Lisa Müller and Bernhard Wessels (2012b) "Demokratiebarometer - ein neues Instrument zur Messung von Demokratiequalität,” Zeitschrift für Vergleichende Politikwissenschaft 6(1):115-159.

Cohen, Joshua (1989) “Deliberation and Democratic Legitimacy," In: (Alan Hamlin and Pettit Philip, Hrsg.) The Good Polity: Normative Analysis of the State. New York: Basil Blackwell, pp. 17-34.

Cohen, Joshua and Archon Fung (2004) "Radical Democracy," Swiss Political Science Review 10(4):23-34.

Collier, Ruth B. and David Collier (1991) Shaping the Political Arena. Princeton: Princeton University Press.

Dahl, Robert A. (1956) A Preface to Democratic Theory. Chicago: University of Chicago Press.

Dahl, Robert A. (1998). On Democracy. New Haven: Yale University Press.

Diamond, Larry and Leonardo Morlino (2004) “The Quality of Democracy: An Overview," Journal of Democracy, 15(4):20-31. 
Diamond, Larry and Leonardo Morlino (2005) “Introduction," In: (dies, ed.) Assessing the Quality of Democracy. Baltimore: Johns Hopkins University Press, pp. ix-xliii.

Dryzek, John S. (1990) Discursive Democracy: Politics, Policy, and Political Science. Cambridge: University Press.

Freitag, Markus (2005) Labor Schweiz: "Vergleichende Wahlbeteiligungsforschung am Beispiel der Schweizer Kantone," Kölner Zeitschrift für Soziologie und Sozialpsychologie 57:667690.

Freitag, Markus (2006) "Bowling the State Back in: Political Institutions and the Creation of. Social Capital," European Journal of Political Research, 45:123-152.

Freitag, Markus and Adrian Vatter (2009) "Patterns of Democracy: A Sub-National Analysis of the German Länder," Acta Politica, 44(4):410-438.

Fung, Archon (2006) "Varieties of Participation in Complex Governance," Public Administration Review, 66-75.

Geser, Hans and François Höpflinger (1977) "Staatsverwaltung und Sozialstruktur: ein Vergleich zwischen vier Kantonen," Schweizerisches Jahrbuch für politische Wissenschaft, 111-135.

Goodin, Robert E. (2007) "Enfranchising All Affected Interests, and Its Alternatives," Philosophy \& Public Affairs, 35(1):40-68.

Gruner, Erich (1977). Die Parteien in der Schweiz. Bern: Francke.

Hamilton, Alexander, James Madison and John Jay (1788) The Federalist. A Collection of Essays, Written in Favour of the New Constitution, as Agreed upon by the Federal Convention, September 17, 1787. New York: McLean.

Hayek, Friedrich August, von (2005 [1960]). Die Verfassung der Freiheit. 4. Aufl. Tübingen: Mohr Siebeck.

Held, David (2006). Models of Democracy. Malden: Polity.

Horber, Eugene and Dominique Joye (1979) “Typologie des cantons suisses,” Annuaire suisse de science politique 19:215-232.

Kaiser, André (1997) “Types of Democracy. From Classical to New Institutionalism,” Journal of Theoretical Politics 9(4):419-444.

Kaiser, André (2002) Mehrheitsdemokratie und Institutionenre from. Frankfurt: Campus.

Kölz, Alfred (1992) Neuere Schweizerische Verfassungsgeschichte. Ihre Grundlinien vom Ende der Alten Eidgenossenschaft bis 1848. Bern: Stämpfli.

Kölz, Alfred (2004) Neuere Schweizerische Verfassungsgeschichte. Ihre Grundlinien in Bund und Kantonen seit 1848. Bern: Stämpfli.

Kriesi, Hanspeter and Dominique Wisler (1996) "Social Movements and Direct Democracy in Switzerland," European Journal of Political Research, 30:19-40.

Kropp, Sabine, Benedikt Giesbers, Nicole Höhmann, Laura Möllers and Matthias Ruschke (2008) “Demokratiequalität im, Ermessen“ der Forschung: Der Vanhanen-Index im Labor der deutschen Länder und Schweizer Kantone,” Zeitschrift für Parlamentsfragen, 39(4):702-727.

Ladner, Andreas (1991) Politische Gemeinden, kommunale Parteien und lokale Politik. Eine empirische Untersuchung in den Gemeinden der Schweiz. Zürich: Seismo.

Ladner, Andreas (2007) “Political Parties.” In: (Ulrich Klöti, et al. Hrsg.) Handbook of Swiss Politics. Zürich: NZZ, pp. 309-334.

Ladner, Andreas and Marc Bühlmann (2007) Demokratie in den Gemeinden. Der Einfluss der Gemeindegrösse und anderer Faktoren auf die Qualität der Demokratie in den Gemeinden. Zürich/Chur: Rüegger. 
Lauth, Hans-Joachim (2004) Demokratie und Demokratiemessung. Eine konzeptionelle Grundlegung für den interkulturellen Vergleich. Wiesbaden: Verlag für Sozialwissenschaften.

Lijphart, Arend (1999) Patterns of Democracy. New Haven/London: Yale University Press. Lijphart, Arend (2004) “Constitutional Design for Divided Societies," Journal of Democracy, 15(2):96-109.

Linder, Wolf (2005) Schweizerische Demokratie. Institutionen, Prozesse, Perspektiven. Bern: Haupt.

Linder, Wolf (2010) Possible Solutions to Conflict in Multicultural Societies. Houndmills: Palgrave.

Lipset, Seymour M. (1959) "Some Social Requisites of Democracy: Economic Development and. Political Legitimacy," American Political Science Review 53(1):69-105.

Locke, John (1963 [1689]) Two Treatises of Government. Cambridge: Cambridge University Press.

Macpherson, Crawford B. (1977) The Life and Times of Liberal Democracy. Oxford: University Press.

Macpherson, Crawford B. (1983) Nachruf auf die liberale Demokratie. Frankfurt: Suhrkamp.

Merkel, Wolfgang (2004) “Embedded and Defective Democracies," Democratization 11(5):3358.

Mill, John Stuart (1859) On Liberty. London: Parker and Son.

Mill, James (1937 [1820]) An Essay on Government. Cambridge: Cambridge University Press.

Montesquieu, Charles de Secondat de (1994 [1748]) Vom Geist der Gesetze. Hg. Weigand, Kurt. Stuttgart: Reclam.

Müller, Thomas and Susanne Pickel (2007) "Wie lässt sich Demokratie am besten messen? Zur Konzeptqualität von Demokratieindizes," Politische Vierteljahresschrift, 3:511-539.

Munck, Gerardo L. and Jay Verkuilen (2002) "Conceptualizing and Measuring Democracy: Evaluating Alternative Indices," Comparative Political Studies 35(1):5-34.

O’Donnell, Guillermo (1994) “Delegative Democracy,” Journal of Democracy, 5(1):55-70.

O’Donnell, Guillermo (2004) “Why The Rule of Law Matters,” Journal of Democracy, 15(4):32-46.

Pateman, Carole (1970) Participation and Democratic Theory. Cambridge: University Press.

Paxton, Pamela, Kenneth. A. Bollen, Deborah M. Lee and Hyo J. Kim (2003) "A Half-Century of Suffrage: New Data and A Comparative Analysis," Studies in Comparative International Development 38(1):93-122.

Peruzzotti, Enrique and Catalina Smulovitz (2006) "Social Accountability.” In: (Enrique Peruzzotti and Catalina Smulovitz, eds.) Enforcing The Rule of Law: Social Accountability in The New Latin American Democracies. Pittsburgh: University of Pittsburgh Press, pp. 3-33.

Pickel, Susanne and Gert Pickel (2006) Politische Kultur-und Demokratieforschung: Eine Einführung, Grundbegriffe, Theorien, Methoden. Wiesbaden: VS Verlag für Sozialwissenschaften.

Pierson, Paul (2000) “Increasing Returns, Path Dependency, and The Study of Politics,” American Political Science Review, 94(2):251-267.

Pitkin, Hanna F. (1967) The Concept of Representation. Berkeley: University of California Press.

Powell, G. Bingham and Guy D. Whitten (1993) “A Cross-National Analysis of Economic Voting: Taking Account of the Political Context," American Journal of Political Science, 37(2):391-414.

Rose, Richard and Philip L. Davies (1994) Inheritance in Public Policy: Change Without Choice in Britain. New Haven, London. 
Rousseau, Jean-Jacques (1762) Du contrat social ou Principes du droit politique. Amsterdam: Marc Michel Rey.

Saward, Michael (Hrsg.) (2001) Democratic Innovation. Deliberation, Representation and Association. London: Taylor and Francis.

Schedler, Andreas (1999) “Conceptualizing Accountability." In: (Andreas Schedler, Larry Diamond and Marc F. Plattner eds.) The Self-Restraining State: Power and Accountability in New Democracies. Boulder: Lynne Rienner, pp. 13-28.

Schmidt, Manfred G. (2010) Demokratietheorien. Wiesbaden: Verlag für Sozialwissenschaften.

Schmitter, Philippe C. (2005) "The Ambiguous Virtues of Accountability.," In: (Larry Diamond and Morlino Leonardo, eds.) Assessing the Quality of Democracy. Baltimore: Johns Hopkins University Press, pp. 18-31.

Selb, Peter (2006) "Multilevel Elections in Switzerland," Swiss Political Science Review, 12:49-75.

Smith, Graham (2009) Democratic Innovations: Designing Institutions for Citizen Participation. Cambridge: Cambridge University Press.

Smulovitz, Catalina and Enrique Peruzzotti (2000) "Societal Accountability in Latin America," Journal of Democracy, 11(4):147-158.

Stadelmann-Steffen, Isabelle and Markus Freitag (2011) "Making Civil Society Work: Models of Democracy and their Impact on Civic Engagement," Nonprofit and Voluntary Sector Quarterly, 40:526-551.

Tocqueville, Alexis de (2006 [1835]) Über die Demokratie in Amerika. Stuttgart: Reclam.

Treier, Shawn and Simon Jackman (2008) “Democracy as a Latent Variable," American Journal of Political Science, 52(1):201-217.

Vatter, Adrian (2002) Kantonale Demokratien im Vergleich. Entstehungsgründe, Interaktionen und Wirkungen politischer Institutionen in den Schweizer Kantonen. Opladen: Leske und Budrich.

Vatter, Adrian (2006) Föderalismusreform. Wirkungsweise und Reformansätze föderativer Institutionen in der Schweiz. Zürich: NZZ.

Vatter, Adrian (2007) "Lijphart goes Regional: Two Different Patterns of Consensus in Swiss Democracies," West European Politics, 30(1):147-171.

Vatter, Adrian and Markus Freitag (2006) “Initiatives, Referendums, and the Tax State," Journal of European Public Policy, 13(1):89-112.

Vatter, Adrian and Markus Freitag (2007) "The Contradictory Effects of Consensus Democracy on the Size of Government: Evidence from the Swiss Cantons," British Journal of Political Science, 36(2):359-371.

Voltmer, Katrin (2000) Structures of diversity of press and broadcasting systems: The institutional context of public communication in Western democracies. Discussion paper FS III 00-201. Berlin: Wissenschaftszentrum Berlin für Sozialforschung.

Young, Iris Marion (2000) Inclusion and Democracy. Oxford: Oxford University Press.

Young, Iris Marion (2001) “Activist Challenges to Deliberative Democracy," Political Theory, 29(5):670-690. 